Indigenous adult women, learning and social justice: challenging deficit discourses in the current policy environment

Dr. Sushan Acharya ${ }^{\mathrm{a}}$, Dr. Catherine M. Jere ${ }^{\mathrm{b}}$ and Prof. Anna Robinson-Pant ${ }^{\mathrm{c}}$

${ }^{a}$ Central Department of Education, Tribhuvan University, Kathmandu, Nepal

${ }^{b}$ School of International Development, University of East Anglia, Norwich, UK

$c^{*}$ School of Education and Lifelong Learning, University of East Anglia, Norwich, NR4

7TJ, UK Email: A.Robinson-Pant@uea.ac.uk

Keywords: indigenous women, informal learning, nonformal education, Nepal, skills development, educational policy, sustainable development 


\section{Indigenous adult women, learning and social justice: challenging deficit discourses in the current policy environment}

Indigenous education engages directly with an overtly politicised process of knowledge construction, recognising and building on existing skills and informal learning practices within communities. Given the 2030 Sustainable Development Agenda's emphasis on social justice and gender equality, this paper sets out to explore what indigenous movements can offer in terms of developing an alternative approach to adult learning based on a rights perspective. The article compares documentary analysis of policy on indigenous women and adult education internationally with a case study of indigenous movements and government policy in Nepal. The analysis reveals that international policy recognises indigenous women as a particularly marginalised group, but is not informed by a transformative notion of empowerment nor consideration of the implications of indigenous knowledge for mainstream education. In Nepal, indigenous federations and the government non formal education programmes similarly aim to impart skills for a modernised economy. However women's indigenous movements are committed to developing capabilities and creating new spaces for indigenous women to engage in political debate and representation. This politicised informal learning offers insights for developing the cross-sectoral rights-based adult education envisaged in the 2030 Sustainable Development Agenda. 


\section{Introduction}

International education policy has long been framed around a deficit discourse - that certain groups lack and need to 'catch up' on the skills and knowledge essential for a successful modern economy - and policy responses to indigenous communities have often taken a similar starting point (Aikman et al 2016). The 2030 Sustainable Development Agenda (UN 2015) offers an opportunity to look again at how indigenous women are addressed within current educational policy discourses, particularly in relation to gender equality and social justice. Does the sustainable development paradigm signal alternative values - such as a belief in sustainable lifestyles - informing educational policy and how does it mediate between an instrumentalist approach and rights perspectives on adult education? Is there now greater policy recognition of the role that education can play in strengthening valuable cultural practices and indigenous knowledge - and of the assets that indigenous people, particularly women, can bring to society?

Overall, the 2030 SD Agenda gives a strong message that indigenous people need to be brought into mainstream education, particularly schooling and formal adult education, positioning indigenous women as a 'vulnerable group' within SDG4 on education. This could be regarded as an assimilationist approach which also assumes 'indigenous' and 'women' to be homogeneous categories (see Rao and Robinson-Pant 2006: 213), rather than exploring intersecting inequalities within each category. By contrast, in this article we begin from the position that rather than simply ensuring the ‘inclusion' of marginalised adults, indigenous education involves acknowledging and building on gendered knowledge, identities and experiences. Recognising the limitations of focusing only on what kind of indigenous knowledge could be incorporated into mainstream curriculum content or looking at indigenous women as a 
particularly 'vulnerable' group who have missed out on schooling as children, our aim is to consider the implications for a broader rights-based approach to adult learning. Central to this discussion is the perceived tension between an education that prepares women to engage with global change, yet can also ensure continuity in cultural ways of learning, determine relevant knowledge and support the development of minority languages.

Indigenous movements are actively addressing questions around the meanings, values and relevance of education (Aikman 2011), which are often missing in policy accounts that emphasise a narrow, instrumental view of education. In this article, we set out to analyse international educational policy through the lens of 'indigenous women' and to develop a case study of indigenous movements in Nepal from a gendered perspective. This comparative analysis is intended to help illuminate ways in which adult education could support the empowerment of indigenous women - and help build greater appreciation of the diversity of cultures, and their contribution to sustainable development (as indicated in SDG 4.7).

\section{Research design and methodology}

This study was designed to develop comparative analysis in terms of:

- Comparing international and national policy perspectives on indigenous women and adult education (through a case study from Nepal)

- Comparing policy stances/discourses within indigenous movements with international and national official educational policy discourses (in Nepal and internationally) 
Our rationale is to develop insights into what indigenous movements might offer to the adult education sector. As well as being academic researchers in this field, we have also played various roles as policy advisers - including working with UNESCO at international and at national level in Nepal - which has influenced our access to and interpretation of policy/programme documentation. The study data consists of policy and programme documentation, including advocacy reports and papers from indigenous movements in Nepal. As a researcher based in Nepal, one of the authors conducted face-to-face interviews with six advocates representing different indigenous forums in Nepal.

This data was analysed using a content analysis approach, similar to that described by Hsieh and Shannon (2005), through generating themes and categories around questions generated by our literature review. For policy documents and educational materials, a discourse analysis approach was adopted (see for instance, Apthorpe and Gasper (1996)), identifying how problems and issues were framed and what appeared to be excluded from consideration within this frame. The latter (i.e. what was not said) was particularly important to take into account in terms of gender - as previous research has indicated that gender is all too often invisible within indigenous adult education (Rao and Robinson-Pant 2006).

\section{Conceptualising literacy, informal learning and gender: a theoretical framework for exploring indigenous adult education}

In many contexts in the Global South, adult education is considered synonymous with ‘women's literacy' (Robinson-Pant 2016), partly because women make up two-thirds of the world's non-literate population. This is particularly so in Nepal where the government has promoted women's literacy for many decades as a strategy to enhance 
economic activity and to support women's roles as mothers and carers (Acharya and Robinson-Pant 2017). Such policy is usually based on what has been termed an 'autonomous' model of literacy (Street 1984), where reading and writing are believed to have specific cognitive benefits. By contrast, our study conceptualised literacy as a social practice (Barton et al 2000), embedded in and shaping everyday relationships and practices - including gendered/indigenous identities and gender relations. This broader understanding of literacy as multimodal and multilingual has particular relevance for indigenous women, offering ways to explore alternative knowledges, skills and literacies. The concept of a hierarchical relationship between 'schooled' or dominant literacy (Street 2004) and indigenous literacy practices is also key to our analysis. The notion of informal learning is integral to these ideas about literacy learning taking place outside formal institutions and classes, through everyday interaction, intergenerational learning and literacy mediators. Tough's (1979) image of an iceberg - where only the formal and nonformal learning is visible above the water level, and the majority of learning is informal learning below the surface - still has resonance with debates about indigenous education where much informal learning is unrecognised and unacknowledged.

Within the field of gender and adult education, we use the distinction between a transformative, rights-based approach and instrumental, functional approach to analyse the differing policy stances adopted by policy makers and activists. In particular, in development discourse, the term 'empowerment' has often come to refer to economic rather than political aims within an instrumental approach, or as an outcome or destination rather than a 'journey' (Cornwall and Edwards 2014). A view of identities as multiple, shifting and performed rather than given (Butler 1990) is particularly 
important to our study in order to analyse if or where policy makers and activists are essentialising gender and cultural identities (often for political reasons). Joshi and Ghose (2012, p. 117) suggest that 'gender continues to be largely understood as being a biological category, with girls and women being identified as "target groups". In the context of indigenous women and adult education, these ideas point to the importance of interrogating ideologies around both indigenous and gender identities and how these may influence educational programme aims.

Bringing together this conceptualisation of literacy, informal learning and gender, we have developed a framework to expand the debate on indigenous adult women and education from the common focus on vocational skills development and education and employment in the formal sector. Above all, these understandings of literacy and identities as situated and dependent on relationships of power and inequality can help to open up a space to discuss how different actors - including international and national government policy makers and indigenous movement activists - view and define the concept of 'indigenous'.

\section{International policy: indigenous women, adult education and learning}

\section{Indigenous Rights and Education}

The right of indigenous peoples to develop and determine their own education systems has been formally acknowledged only relatively recently. This section analyses some of the historical developments by indigenous movements that have influenced educational policy and helped to shape what is considered to be 'Indigenous Education'. The draft Declaration on the Rights of Indigenous Peoples (UNDRIP), as revised by the Working Group on Indigenous Populations in 1993, and only formally adopted in 2007 (Table 1), 
helped to establish this right, asserting that indigenous peoples have the right to establish and control their educational systems and institutions providing education in their own language (Article 14) (UN, 2008).

At around the same time, the Kari-Oca Declaration entitled 'Indigenous Peoples' Earth Charter' (formulated in Brazil in 1992) included similar statements: 'Indigenous peoples should have the right to their own knowledge, languages and culturally appropriate education, including bicultural and bilingual education. Through recognizing both formal and informal ways the participation of family and community is guaranteed.' (World Conference 1993:3) As well as emphasising the importance of being able to use indigenous languages and of indigenous people having resources and control over their own education systems, this statement also highlighted the central role of the community, particularly older people, in sustaining indigenous learning and knowledge: 'Elders must be recognized and respected as teachers of the young people. Indigenous wisdom must be recognized and encouraged' (ibid:7).

These early statements led to the preparation of the Coolongatta Statement on Indigenous People's Rights in Education at the World Indigenous Peoples' Conference on Education in Hilo, Hawai'i, 1999. Giving the background of indigenous peoples' oppression under colonialization and the purpose of (non-Indigenous) education being 'to assimilate Indigenous peoples into non-Indigenous cultures and societies' (WIPCE 1999), this statement outlined in greater detail an alternative approach to Indigenous Education. Emphasising that drop-out rates or poor educational results should be seen as 'rejection rates' and a failure of the system rather than of an individual, it argued that non-Indigenous education systems 'have failed to provide educational services that nurture the whole Indigenous person inclusive of scholarship, culture and spirituality' (ibid). There is recognition of the challenge of how to "promote, protect and nurture 
Indigenous cultures in an ever-changing modern society' and that Indigenous people should be free to decide whether they prefer to participate in non-Indigenous Education systems. The role of non-verbal communication is highlighted, and the notion that 'indigenous learning is clothed in the medium of spirituality' (ibid).

What comes across strongly in the Coolongatta Statement is the different form and purpose of Indigenous Education (as opposed to 'education for indigenous people') and the difficulty of developing and sustaining these alternative ways of learning, knowing and being through mainstream education systems. The problem is around being evaluated within a system with conflicting values: 'Invariably the nature, and consequently the outcome, of this education has been constructed through and measured by non-Indigenous standards, values and philosophies' (ibid). The Statement outlines the right to self-determination in indigenous education through principles that include 'To establish schools and other learning facilities that recognize, respect and promote Indigenous values, philosophies and ideologies'; and 'to promote the use of Indigenous languages in education. The statement recognises that Indigenous Peoples are not homogeneous in terms of different philosophies and values in different parts of the world, but there is no mention of differences within indigenous communities - apart from generational. Though women are singled out as a specific target group - 'particular attention should be given to indigenous women, children and youth' (ibid) - this seems to be more in terms of their particular needs, or perceived vulnerabilities, rather than different knowledge or gendered experiences or identities.

Moving forward to 2017, the 61st Commission on the Status of Women (CSW61) convened at the UN Headquarters in New York, included a session challenging the stereotypical portrayal of indigenous women as victims rather than agents of change. Indigenous women leaders stated 'their need for rights to economic 
empowerment, education and their right to be part of decision making processes for solutions to worldwide problems'. Aminatu Samiratu Gambo (Mbororo) of the Indigenous Information Network Kenya and Cameroon argued that indigenous men needed to give women the space so that 'we can be heard and our situations will be resolved'. As well as the need for more decision-making powers within their communities, this forum highlighted the important role of indigenous women as 'champions of sustainability', being profoundly affected by climate change; more akin to an instrumental perspective on the role of indigenous peoples for sustainable development, a perspective also upheld by the Rio Declaration of 1992 (Table 1). Clearly, indigenous education is a highly politicised field and the demands of indigenous movements go beyond the right to access education. The inclusion of indigenous people within non-indigenous education systems is regarded as problematic in terms of sustaining indigenous values, cultures and languages. Although no distinction is made between adult education and schooling in the Coolongata Declaration, the issues around the promotion of informal, intergenerational learning, indigenous languages, and the need for resources to develop indigenous education curricula, all link clearly to the notions of literacy as a social practice outlined earlier. The stated aspirations for indigenous education above are grounded in an understanding that learning is shaped by hierarchies of languages, knowledges and social relationships - and that these can be challenged through education.

From this account of the developing concept of indigenous education that emerged from indigenous movements, we move now to consider international policy declarations, from the 1960s to the present day. The following section looks particularly at declarations produced by United Nations organisations, with a focus on education, to analyse how and when indigenous women and adult learning have been 
addressed. Through an historical analysis of these declarations, we set out to identify how the term 'indigenous' has been viewed and defined by different actors within educational policy spaces, and take the instrumental/rights dichotomy to explore the kind of learning and knowledges being promoted in relation to women's empowerment.

Figure 1

\section{International instruments: aims and recognition for indigenous women, their}

\section{knowledge and learning}

There is no internationally agreed definition of the term 'indigenous peoples.' The UNDRIP identifies indigenous peoples as those under the protection of the Declaration, without defining the term itself; nor, given the vast diversity of peoples it encompasses, has formal definition been deemed either "necessary or desirable" (ILO, 2009, p. 9). The Indigenous and Tribal Peoples Convention (ILO No. 169) offers criteria to help identify - rather than define - such peoples. These include an historical attachment to ancestral territories, distinct social, cultural, political and economic institutions, and their own languages, knowledge systems and beliefs (Vinding \& Kampbel, 2012). Selfidentification is considered a fundamental criterion (ibid). UN programmes and international agencies, used similar criteria to develop operational coverage of indigenous peoples, eschewing strict definitions.

However, prior to the 1990s, with its flagship Earth Summit in Rio and the emergence of the Education for All agenda, UN conventions made no specific mention of indigenous women, and, whilst indigenous knowledge systems were clearly acknowledged, adult education was not prioritised (Table 2).

The International Committee for Economic, Social and Cultural Rights (ICESCR), in their General Comments (GC) on the 1966 Convention draws intrinsic links between education (Article 13) and rights to a full cultural life. (Article 14), seeing education as 
a means to allow communities and individuals to pass on their values, religion, customs and language. Yet within the Convention on the Elimination of All Forms of Discrimination against Women (CEDAW) framework, culture and tradition are viewed only in terms of its deleterious effect on girls and women's access to education. There is no acknowledgement of indigenous knowledge and, for women, access to modernising reproductive health information is prioritised (Table 1).

The ICESCR GC 13, published in 1999, extends the requirement of fundamental - or basic - education to all those whose basic learning needs have not been met, without restriction by age or gender. It notes 'Fundamental education, therefore, is an integral component of adult education and life-long learning. Because fundamental education is a right of all age groups, curricula and delivery systems must be devised which are suitable for students of all ages' (CESCR, 1999: 24). As such, GC 13 places additional emphasis on the 'adaptability' of education provision, curricula and learning methods to meet basic learning needs of all, and laying the groundwork for greater emphasis on non-formal education for adults.

Through our analysis of these international conventions, a dichotomy emerges and is sustained - between the recognition of the value of indigenous peoples, and their knowledge, for sustainable development, and an education-led discourse that sees indigenous peoples as underserved, disadvantaged and needing to be accommodated within established education systems.

An exception is the Beijing Declaration and Platform for Action, adopted at the 1995 Fourth World Conference on Women, which makes comprehensive reference to indigenous women. It recognises the traditional knowledge innovations and practices of indigenous women in particular as a form of lifelong learning and calls for respect for 
their artistic, spiritual and cultural activities (Table 1), whilst, at the same time, acknowledging their position as a previously underserved group.

Table 1

The Dakar statement acknowledges that a key challenge for the goal of Education For All is that of building a more inclusive concept of education, and reflecting this in international and national policies. Whilst the World Education Forum in 1990 highlights indigenous groups as underserved (Table 2), the overall Dakar statement's list of disadvantaged groups does not include indigenous groups, a term dropped, but perhaps assumed to be encompassed by 'remote rural dwellers and nomads, and ethnic and linguistic minorities'.

In the regional Frameworks for Action under Dakar, the Sub-Saharan framework makes the most notable reference to indigenous peoples, recognising that, 'African indigenous knowledge systems, languages and values should be the foundation for the development of African education systems (Preamble, p 21).' As such, the framework and calls for a review of curricula and validation of African indigenous knowledge systems, values and skills, including the development and publication of textbooks in indigenous (African) languages. Yet definitions of indigenous are not clarified, and appear to counterpoint colonial languages rather than concern specific minority groups, pastoralists, or indigenous peoples. Nor does it voice ideas or strategies relating to the validation or uptake of indigenous knowledge systems. In the Americas Regional Framework, indigenous groups are referenced in relation to the full participation and integration of disadvantaged groups, again taking a strong normative stance to inclusion. The Asia and Pacific Regional Framework, whilst acknowledging previous 
lack of alternative, non-formal approaches to basic education as a key challenge, gives little attention to adult literacy and lifelong learning; the exception being in relation to harnessing media and new technologies. There is no mention of indigenous peoples or knowledge systems.

Table 2

Where policy indicates an instrumental approach, there is little detail about what kinds of indigenous knowledge and learning might support sustainable development. These international policy declarations rarely defined what was meant by 'indigenous' (other than as an oppositional term to 'colonial'), tended to focus on formal and nonformal, rather than informal learning, and failed to address indigenous women as a distinct group of actors, except in carrying the burden of a deficit labelling. The Belém Framework for Action - with its focus on adult education - whilst acknowledging the importance of literacy and learning in indigenous languages, reiterates a perspective of indigenous women as a 'highly disadvantaged group' (Table 2).

Pertinent to the following Nepal case study, an analysis of the South Asian Association for Regional Cooperation (SAARC) ${ }^{1}$ New Delhi Declaration on Education', developed to adapt and prioritise EFA areas of action in the run up to 2015, found no explicit mention of indigenous peoples. Instead, priority areas follow a normative stance, emphasise formal schooling and are indicative of a singularly instrumental approach to education (SAARC, 2015).

\footnotetext{
${ }^{1}$ Consisting of Afghanistan, Bangladesh, Bhutan, the Maldives, Nepal, Pakistan and Sri Lanka
} 


\section{The post-2015 era and the SDG 2030 Agenda}

The 2030 Agenda for Sustainable Development starts from the premise that all people, 'irrespective of sex, age, race, ethnicity, and persons with disabilities, migrants, indigenous peoples, should have access to lifelong learning opportunities'. Indicators for SDG4 (the education goal) are in place to monitor access to learning for groups identified as 'underserved' and 'disadvantaged'; at risk of being left behind in the achievement of SDG goals. As with the Jomtien and Dakar declarations, indigenous peoples are mentioned as one such group, carrying a deficit label, but without clarification of what is meant by 'indigenous'.

By 2030, eliminate gender disparities in education and ensure equal access at all levels of education and vocational training for the vulnerable, including persons with disabilities, indigenous peoples and children in vulnerable situations -

\section{Target 4.5}

Indicators for target 4.5 of the SDG goal for education include measures for equity to monitor the progress of 'disadvantaged' groups. Global Indicator 4.5.1 sets out a requirement for parity indices for all indicators that can be disaggregated. Indigenous peoples are a candidate for such a parity index, as data becomes available. Currently, one in six national censuses asked about indigenous status (UNESCO, 2017), yet data are very limited and may be distorted by definition and perception biases.

The only other target within the SDG Agenda that specifically mentions indigenous peoples is Target 2.3., which relates to increased agricultural productivity and incomes of 'small-scale food producers, in particular women, indigenous peoples, family farmers, pastoralists and fishers': a target that risks returning focus to predominantly instrumental role for indigenous groups and a 'modernising' agenda. There is no clear recognition of indigenous knowledge, nor the rights of indigenous 
peoples to protect and develop that knowledge, as reflected in earlier international instruments on sustainable development (e.g. Rio Summit and UNDRIP) (Table 1).

The above analysis highlights this disconnect between the previously emerging recognition of the intrinsic value of indigenous peoples' knowledge systems and culture (e.g. in the EFA global framework), and policymakers' insistence that such groups be better integrated into mainstream education and economic systems (what we described earlier as the dominant deficit discourse). Ironically, the move from the broad EFA agenda to today's SDG framework - with its emphasis on 'leaving no one behind' - sees a shift from a fundamentally rights-based recognition of indigenous peoples and their heritage in global education policy (Table 2) to one of assimilation that risks negating agency and a potentially transformative role for women's indigenous knowledge.

\section{Indigenous women, adult learning and education: the case of Nepal}

At this point, we turn to our case study of Nepal, to consider how these issues have shaped national policy development. As well as looking at how 'indigenous' has been defined, we investigate how/whether indigenous women's knowledge and learning has been recognised within national policy.

Nepal has embarked on a process of federalisation, whereby seven provinces replaced the former 14 administrative zones with devolved administrative and financial authority. The newly created provincial assemblies are currently engaging with questions around which languages, indigenous values and cultures to recognise and promote within government institutions, including 
schools. This section draws on interviews and documentary analysis conducted in Nepal at this critical point of national policy development and debate.

A majority of the population still follow the Hindu religion in Nepal. Formerly, Hinduism was widely practised and promoted primarily because this was the religion of the monarchy, so other indigenous religions and cultures were practised within community circles with limited visibility. Since the 1990 People's Movement brought the absolute monarchy to an end, indigenous cultures and languages have been gradually recognised more widely. The interim Constitution in 2007 ensured the right for every religion to maintain 'its independent existence, manage and protect its religious places and religious trusts' (23/2 Right to Religion). This was further strengthened by the Constitution of Nepal 2015, which established Nepal as a secular state and protects religious and cultural freedoms (26/3, Right to Freedom of Religion).

Many indigenous people still celebrate both the Hindu festivals and their indigenous religion and cultures. Conversion to Christianity among the indigenous population is also growing through the concerted effort of missionaries. Indigenous people are finding it economically and physically convenient to visit local churches, rather than to follow indigenous practices such as worshipping the forest. Thomas et al (2012: 34) note that 'many Chepang [an indigenous group] are moving from traditional to Christian beliefs, and use of traditional healers is being replaced by belief in prayer to cure ill-health'. In this dynamic situation, the questions 'what is indigeneity?' and 'how can indigenous identity can be preserved?' have gained in importance.

\section{How are indigenous people and indigenous knowledge defined in Nepal?}

There are several national level bodies/organisations whose work has helped to inform 
definitions of 'indigenous'. Three of the most prominent are:

- The National Foundation for the Development of Indigenous Nationalities in Nepal (NFDIN), a government organisation founded in 2002 under the Ministry of Local Development

- The National Federation of Indigenous Nationalities $(\mathrm{NFIN})^{2}$, formed in 1991 as an autonomous, non-partisan, national level umbrella organisation of indigenous peoples

- The National Indigenous Women's Forum (NIWF), established in 1998, a consortium of 41 indigenous women's organizations.

According to the NFDIN and NEFIN, indigenous people are those who have a distinct collective identity, their own language, religion, tradition, culture and civilization, their own traditional egalitarian social structures, traditional homeland and geographical area, written or oral history and the feeling of 'We' (NFDIN, 2017 \& NEFIN as cited by Sherpa, 2009). NEFIN has further added two more characteristics those who have had no decisive role in the politics and government of modern Nepal and those who declare themselves as 'Janajati' or 'Adivasi'3 (ibid). In Sherpa's (2009) research, respondents (both those actively involved in indigenous issues and those not) all identified lack of political representation, educational opportunities and access to

\footnotetext{
${ }^{2}$ NEFIN is a member of the United Nation's Working Group on Indigenous Populations

${ }^{3}$ Leading indigenous scholars coined the terms Janajati (nationality) and Adivasi (indigenous people) to identify populations outside of the Hindu caste hierarchy (Neupane, 2012). These days the two terms are used interchangeably in Nepal and both refer to indigenous people.
} 
health care along with distinct culture, language and religion as important characteristics of indigenous people of Nepal.

Indigenous academics and advocates working for indigenous rights interviewed for this paper suggested that 'indigenous' is related to those who are original inhabitants. A male university lecturer identified them as 'Those who have high adaptation with nature... though they are modernized, they hold indigenous knowledge'. This notion of indigenous peoples' proximity to nature was seen to shape their knowledge too. A male lecturer from an indigenous group noted: 'Their identity is formed in relation to land and nature. Their corpus of knowledge is not recognized'.

The Nepal research literature has defined indigenous knowledge as knowledge produced, utilised and transmitted across generation by a distinctive cultural group who are resource users of certain area (Maden, Kongren \& Limbu, 2008, and Limbu, 2015). In the policy context, the Ministry of Science, Technology and Environment (MoSTE) also agrees that indigenous knowledge is tacit but practical knowledge accumulated over the years and transmitted orally and through experiences from generation to generation and that it is constantly changing (MoSTE, 2015). In reference to indigenous knowledge and practices for climate change resilience MoSTE indicates that Nepali women's knowledge, skills and their capacity to respond to some challenges generated by climate change, and natural resource management are extensive but lack of access to power and resources "that would enable them to turn knowledge into solution" (p. 36). Indigenous women are recognized as the "custodians of traditional knowledge and skills" (ILO, 2012), particularly in relation to traditional food preparation and preservation, wine making, weaving and handicrafts, honey gathering and herbal medicine (ibid; Rai 2018; Limbu 2015). Indigenous women's knowledge in natural resource management is also immense (Magar, 2009). 
The sustaining and development of this kind of knowledge was recognised by our respondents as dependent on power relationships with the State. An indigenous advocate (male) referred to knowledge as 'Customary practices that are different from that of the Modern Nation State' and argued that '...how much that community remains or continues such knowledge and practices determines indigeneity'.

Indigenous knowledge is considered to be both a process and product of knowledge building, and represented through language, as a female linguist from an indigenous community explained: 'Any word or terminology that is not found in indigenous people's language is not indigenous knowledge'.

Thus indigenous knowledge, as defined by our respondents, includes any local knowledge that is used and/or practised by original inhabitants; experiential knowledge in tacit form acquired through interaction with nature; and recognition of the uniqueness of the community's knowledge building process, including differences from that of the modern nation state. However, the characteristics of indigenous people appeared to be challenged in the changing social and economic context of Nepal. Although there is a consensus among Adivasi or Janajati regarding the definition of indigenous, questions arise around whether the term can still hold if an individual becomes more economically, educationally, socially and geographically mobile. For instance, there is debate currently about whether the characteristics apply to all those who are born into a particular indigenous community, irrespective of whether they later change location, religion, culture or language, or whether individuals can be considered indigenous if they only hold on to one characteristic, such as participating in certain cultural events? 
Though many indigenous people are still living in rural areas maintaining many traditional practices, many others have changed practices in their everyday life and culture - due to the long lasting influence of Hindu traditions, increased migration among young members and conversion to Christianity. Some indigenous intellectuals opined that how much a community remains or continues customary knowledge and practices determines indigeneity, as noted by an activist in relation to her own identity:

'In terms of practising and exercising, I am not an indigenous now due to forceful state mechanisms that never supported indigenous people to live with their traditional knowledge and practice. Since we have ties with that indigenous community who followed indigenous knowledge and practices we are considered indigenous but we are not doing the same.'

She also attributed this situation to the cultural practices brought by indigenous population who have travelled to other parts of the world and the impact of assertive religious conversion. In addition, Thapa Magar (2009) identified the intervention of new technologies as one of the causes of deteriorating indigenous knowledge.

The Nepal case demonstrates the long standing tension between the indigenous population and the State that surfaced after the restoration of democracy in the 1990s. One of the major areas of tension has been the issue of identity. Changes in sociocultural status also sped up due to increased, improved technology and the inflow of development agencies. Changes in location and socio-cultural contexts brings into question the definition of indigenous and indigeneity in Nepal. This will lead, potentially, to another layer of tension as multiple identities are shaped and indigeneity recognised in different ways in the globalised context. 


\section{Indigenous women's movements in Nepal}

There are an ever-growing number of organisations actively working to ensure the rights and development of indigenous people in Nepal, including the NFDIN, NEFIN and NIWF. There are also indigenous women's organisations and research/sectorspecific organisations such as the Indigenous Women's Legal Awareness Group (INWOLAG). Identity-based Indigenous People's Organizations (IPOs) have been formed in efforts to create shared identities while recognizing the differences that exist within ethnic groups (Hangen, 2009). This paper reviews the initiatives of NFDIN, NEFIN and NIWF, with a particular focus on how they address gender issues, and recognise indigenous knowledge and women's learning.

NFDIN works in different districts through separate units, which include: programmes for endangered indigenous communities, income generation and skill development, research, publications, community building, construction and Civil Service examination preparatory classes (NFDIN, 2015). For example, support was provided to Nepal Magar Women's Association for tailoring training for women in Bardia district (NFDIN, 2017), training on investigative journalism for indigenous women and men, and an ethnolinguistic survey (NFDIN, 2015). Such programmes are either implemented directly or through IPOs.

One of NFDIN's objectives that has potential to enhance indigenous women's knowledge and learning, is to preserve and promote the traditional knowledge, skills and technologies of the Janajati and to guide their vocational use (NFDIN, 2017). However, programmes that address the above-mentioned objective are rarely found in NFDIN documents, and NFDIN objectives do not refer explicitly to issues of gender. 
The NWIF recognises that indigenous women face distinct and different issues from that of other women, and from indigenous men. The rationale for its formation was that indigenous women's issues were not adequately addressed by established indigenous organizations or forums - where men tended to dominate. According to a female social worker respondent, intersecting inequalities that indigenous women faced were often hidden:

'Informally janajati women have raised their voices that they bear double discrimination as women and being a janajati woman. But it has not been raised strongly.'

This view was supported by an indigenous activist, who maintained that,

There is a notion that there is gender equality in Janajatis then there is no need to write about gender issues... If someone tries to talk about differences or diversity among Nepali women relating to particular ethnic group, then that person is seen as disturbing the harmony.

This reflects Hangen's (2010: 43) observation that 'as in most political sectors in Nepal, gender inequality has been persistent within indigenous nationalities movement. Participation of women in all aspects of movement is limited'.

The NIWF also points out that traditionally indigenous women are decision makers in the family and society, and contribute to peace building and reconciliation, which the State has not recognized. They have two objectives relevant to addressing gender inequities: (1) to support economic, linguistic, social, religious, political and cultural aspects of indigenous women, and (2) to research and analyse issues related to the social situations of indigenous women and intervene accordingly (NIWF, 2017). 
Their strategies include: promote gender equity and equality; literacy and education campaigns; deconstruction of ideological, political, socio-cultural, linguistic, religious, and institutional barriers against indigenous women, and construction and/or reconstruction of indigenous women's identity, dignity, status and rights ${ }^{4}$.

\section{Indigenous movements and adult learning}

NIWF has been implementing projects and programmes geared towards the empowerment and development of indigenous communities perceived as those most marginalized and endangered; political and social advocacy to ensure rights of indigenous population in general, and indigenous women in particular, and skill-based trainings for economic improvement. However, a progress report of the projects implemented from 1998 to 2013 (NWIF, n.d) indicates that the majority focused on transferring modern skills and knowledge related to occupations, advocacy about indigenous people's rights and anthropological studies of the communities. A review of projects that aimed to address gender inequities within endangered indigenous communities revealed that most were not utilizing or promoting women's indigenous knowledge as a vehicle to empowerment. For instance, a community literacy programme for endangered indigenous women implemented by NIWF (2003/04) was not that different from other mainstream literacy programmes, focusing only imparting new knowledge, rather than building on participants' indigenous skills.

There have, however, been several projects around securing new spaces for indigenous women to have a voice in the political and social processes of the State. A five year (2001-2006) project for the empowerment of indigenous people funded by

\footnotetext{
${ }^{4}$ See http://niwfnepal.org.np/strategies/
} 
German Development Service (DED) included components addressing social discrimination faced by indigenous women and an advocacy programme for increasing the inclusion of indigenous women in the then Constitution Assembly. Two later NIWF projects included capacity-building activities with village and district level democratic fora, such as conducting discussions with service providers and local women politicians in the area of human rights; situation analyses of indigenous women's issues; publication of a training manual, and formation of indigenous women's networks locally. NIWF continues to advocate for indigenous women's rights and political space at the national level. A recent programme has established monthly dialogue groups with young indigenous women on indigenous culture, politics, book reading and art and activism and radio journalism training (NIWF, 2017). However, there is little indication that means to integrate and build on indigenous women's knowledge in these projects' processes was considered.

The NIWF recognises that indigenous women retain some or all of their distinctive knowledge, skills, culture, decision-making roles and traditional institutions, and play a vital role in sustainable management of environment and natural resources. Yet, the goal and objectives of NIWF are more inclined towards gaining political rights on the basis of ethnic, linguistic and regional autonomy with the right to selfdetermination and ensuring space in State structures. Promoting, preserving and utilizing indigenous women's knowledge, skills and capacity are not made explicit in their objectives.

This review of indigenous federations reveals that indigenous women's knowledge, skill and capacities have rarely been considered as important resources within their programmes. Instead, the focus has been on creating space and identity for indigenous women in the State structures through advocacy and capacity development, 
and taking care of their immediate needs through relief work. The indigenous women's movement has also focused on addressing inequalities in formal schooling, rather than advocacy for integrating indigenous knowledge through non-formal education. A social worker from an indigenous group commented that,

...not much effort has been made to record, promote and link indigenous knowledge with mainstream discourse. Focus has been given to skill promotion and preservation.

As Rai (2016) notes, indigenous nationalities' focused fight against the State's discrimination, and the effect of the State's single policy and Hinduization, has envigorated their struggle. However, in research literature, indigenous women are mostly presented from cultural and social perspectives alone and other important aspects of their lives are not given space (ibid.).

The indigenous movements have influenced government education policy and programmes through advocacy for literacy in mother tongue languages. NFE is recognized as a mechanism to preserve and promote local cultures, local knowledge and traditional skills (NFEC, 2016 \& 2017). Government-prepared primers (ibid) teach adult learners about their right to use their mother tongue and women's rights. The primers cover the use of local technology and measures to protect water, land, forest, herbs and animals. However, neither the primers nor facilitator's training manual recognize that the learners are mostly women. The emphasis is more on imparting knowledge and skills, than promoting the indigenous knowledge that women come with, and there is no reference to intergenerational learning. The mind-set behind the NFE materials and delivery appears guided by a 'banking concept' of education that 
gives little room to integrate women's indigenous knowledge and skills into teaching and learning processes.

\section{Indigenous adult women and learning: combining international and national perspectives}

Our earlier analysis of international documents reveals a discourse that positions indigenous communities as an underserved and disadvantaged group, alongside increasing recognition of their right to education (particularly schooling) in their mother tongue. Within the 2030 Sustainable Development Agenda, as with previous international instruments on sustainable development, there is still no clear recognition of a role for women's indigenous knowledge. Significantly, it was the gender-focused Beijing Platform for Action that made greater reference to indigenous knowledge as a form of lifelong learning and called for protection and use of the knowledge, innovations and practices of indigenous women. Taking gender rather than education as the starting point may have led to the focus on informal learning and indigenous knowledges rather than formal or non-formal education within the Beijing declarations. Within our earlier review of educational policy instruments, the emphasis appeared to be on ensuring greater access to skills development for indigenous groups (as in the Belem Framework for Action) - what might be seen as an instrumental rather than a transformative approach to women's empowerment.

By contrast, the case study of indigenous movements in Nepal suggests that transformative political goals have largely informed their educational agenda, which focuses on capacity building in terms of indigenous women gaining new spaces for political representation. Although this process involves informal learning, these organisations' explicitly stated educational objectives are framed around catching up on technical skills and formal literacy. The review of skills development and literacy 
programmes for indigenous women points to a lack of attention to utilising, preserving or finding ways to facilitate intergenerational learning of indigenous knowledges rather, they tend to replicate mainstream women's education programmes. Seen from the perspective of multiple identities and multiple literacies, such programmes tend to have prioritised 'schooled' literacy (Street 2005) and overlooked such groups' distinct identities and knowledges as indigenous women. Within this context, 'indigenous education' is interpreted in terms of new skills and capabilities to initiate political reform - rather than focusing on how to preserve and sustain indigenous knowledge.

The questions raised by the Nepal case study around notions of changing identities and definitions of indigeneity relate to the tensions identified within international policy between the value of indigenous knowledge for sustainable development and the recognition that indigenous people need to access new knowledge. Does someone cease to be 'indigenous' when they move away and lose indigenous skills/languages? The highly politicised notion of 'indigenous' in Nepal - as embedded in long-standing relationships with the State and religious hierarchies - challenges international educational policy instruments which are only focused on one dimension of empowerment, particularly the economic. Similarly, the invisibility of gender inequality within some indigenous communities and movements in Nepal signals the importance of ensuring political mobilisation is also gendered - rather than only focusing educational interventions on indigenous women as a doubly disadvantaged group.

Significantly, most of the activities conducted by indigenous movements in Nepal were promoting informal learning for women - whether through discussion forums or political awareness raising. It is not clear how far the formal institutions reviewed here have harnessed the potential of social media to support this learning, 
though use of mobile phones and digital literacy is widespread amongst women in indigenous communities.

\section{Conclusion}

This article set out to look at what indigenous movements can offer in terms of problematising and challenging the SDGs to develop an expanded and cross-sectoral approach to adult learning. In particular, the sustainable development paradigm implies a greater recognition of the impact of climate change and environmental degradation, which has long been a central concern of indigenous movements, and exploring what kind of skills/knowledge might be needed. Although there is a greater focus on educational inclusion in the SDGs, there are questions around how far there is an intended space for groups like indigenous women to influence the values and knowledges within mainstream education. This could be seen as the distinction between 'education for indigenous adults', as compared to 'indigenous adult education'. As Morrison (2011) points out, taking an 'indigenous' perspective on education involves interrogating educational content and dominant practices like measuring quality in relation to international 'standards'. In our analysis, we found that education initiatives within the Nepal context and within international policy declarations tended to replicate such dominant models, focusing on development of skills for the modern economy. 'Indigenous education'- in the sense of alternative values and educational approaches was neither promoted by the indigenous movements (who focused on more formal skill training) nor mainstream educational providers.

Taking a broader lens on adult education as involving informal and intergenerational learning, we could however take the indigenous movements' work on political awareness-raising as exemplifying a 'rights' perspective on skills development. Rogers (2013) distinguishes between different kinds of informal learning: incidental, 
task-conscious, self-directed and/or unintentional. Through this lens, we can see that whilst international policy and indigenous movements may promote new political spaces as a way of supporting indigenous women's informal learning in terms of leadership and voice ('task-conscious' learning), there is less attention given to how to build on established self-directed and unintentional processes of informal and intergenerational indigenous learning. In other words, indigenous education is rarely taken as a different approach to learning - rather, the emphasis is on ensuring the better integration of indigenous women into the dominant discourse, whether that means mainstream political structures or formal educational institutions. By contrast, taking intergenerational learning as integral to indigenous education might involve questioning taken-for-granted hierarchical relationships between teachers and students within formal education or challenging the tendency to teach literacy as a decontextualized skill, rather than as embedded in social and cultural practices.

As the above analysis has revealed, the assumed dichotomies between instrumental and rights approaches cannot be simply mapped onto that of formal and informal learning - as revealed by the case study from Nepal, formal schooling may also be seen as key to indigenous women gaining greater political voice and representation. Similarly, indigenous movements may see strategic reasons for essentialising gender and culture (rather than recognising indigenous women's multiple identities and literacies) in order to strengthen cohesion within the organisation for political mobilisation. Moving towards the 2030 SD Agenda, the challenge is also how to strengthen the connections between informal, nonformal and formal learning and recognise indigenous women's diverse identities and knowledges. in order to develop the processes for catalysing sustainable development and the expanded notion of 
knowledge and skills signalled by SDG 4.7 around 'global citizenship and appreciation of cultural diversity’.

\section{References}

Acharya, S. and A. Robinson-Pant (2017) Women, literacy and health: comparing health and education sectoral approaches in Nepal, Compare, http://www.tandfonline.com/doi/full/10.1080/03057925.2017.1393622

Aikman, S. (2011) Education and indigenous justice in Africa, International Journal of Educational Development, 31, pp 15 - 22

Aikman, S., Robinson-Pant, A., McGrath, S., Jere, C., Cheffy, I., Themelis, S., Rogers, A. (2016) Challenging deficit discourses in international education and development in Compare: a journal of comparative and international education 46, pp. 314-334

Apthorpe, R. \& D. Gasper (1996) Arguing development policy: frames and discourses, London: Frank Cass

Barton, D., Hamilton, M. and R. Ivanic (2000) Situated Literacies: Reading and Writing in Context, London: Routledge

Butler, J. (1990) Gender Trouble: Feminism and the subversion of identity, London: Routledge

Cornwall, A. and J. Edwards (2014) Negotiating Empowerment. In Cornwall and Edwards (eds) Feminisms, Empowerment and Development: Changing Women's Lives, London/New York, Zed Books

CESR (1999) General Comment 13, New York, UN Economic and Social Council

Hangen, I. S. (2010) The rise of ethnic politics in Nepal: Democracy in the margin. Oxford: Routledge.

Hsiu-Fang Hsieh and S. E. Shannon (2005) Three Approaches to Qualitative Content Analysis, Qualitative Health Research 2015, 15: 1277

ILO (2009). Indigenous and tribal peoples' rights in practice: a guide to ILO Convention No. 169 Retrieved from

http://www.ilo.org/newyork/publications/WCMS_106474/lang--en/index.htm

Joshi, S. and M. Ghose (2012) India: Literacy and women's empowerment, a tracer study. In ASPBAE (2012) The power of literacy: women's journeys in India, Indonesia, Philippines and Papua New Guinea, Philippines: ASPBAE

Limbu, R. K. (2015). Limbu Indigenous Knowledge and Culture. Lalitpur: National Foundation for Development of Indigenous Nationalities. 
Maden, K., Kongren, R. and Limbu T. M. (2008). Docunmetation of indigenous knowledge, skill and practices of Kirant nationalities with special focus on biological resources. Unpublished Research. Lalitpur: SNV-Nepal.

Magar, T.S. (2009) Magars and their indigenous knowledge systems and practices in Tanahu district of Nepal. Occasional Papers in Sociology and Anthropology. Vol. 11. Page, 67-83.

MoSTE (2015). Indigenous and Local Knowledge and Practices for Climate Resilience in Nepal, Mainstreaming Climate Change Risk Management in Development, Ministry of Science, Technology and Environment (MoSTE), Kathmandu, Nepal.

Morrison, S. (2011) Quality adult education benchmarks for indigenous education, prepared as a discussion paper for ASPBAE, June 2011, Asia South Pacific Association for Basic and Adult Education.

Neupane, F. (2012) Adivasi and Janajati: Indigenous People and Nationalities in Nepal. Parivartan Nepal. Accessed from: https://parivartannepal.blogspot.com/2012/01/adibashi-andjanajati-indigenous-people_04.html

NFDIN (2017) Cutting and sewing training for Magar women. Accessed from: http://www.nfdin.gov.np/

NFDIN (2017) Introduction and Objectives, . Accessed from: http://www.nfdin.gov.np/eng

NFDIN (2003) National Foundation for Development of Indigenous Nationalities: An introduction. Kathmandu: Author.

NIWF (2017) Past to present of National Indigenous Women's Forum. [In Nepali]. Accessed from: https://drive.google.com/file/d/0B_DP4QnD9yPQOHp5X2QwX2tnLUU/view

Non Formal Education Center (2007) Non Formal Education Policy. Kathmandu: Ministry of Education.

NFEC (Non Formal Education Center) (2016) Continuing education facilitator's training manual 2073. (In Nepali) Kathmandu: Author.

NFEC (2017) NFE and continuing education programme implementation guideline. Kathmandu: Author.

Rai, I. M. (2018). Identity paradoxes of Kirat migrants in urban context: An Auto/ethnographic inquiry. A Thesis submitted to Kathmandu University.

Rai, K. (2016) Indigenous women's social movement. [In Nepali] In Kailash Rai (ed), In search of identity. Indigenous women's social, cultural and political contexts. Indigenous Media Foundation, pp 145-160. 
Rai, K. (2017) Nepal government's policy and international provisions in relation to indigenous women and children [In Nepali]. In Thami \& Chhantyal (eds) Indigenous rights in Nepal: Policy situation, challenges and opportunities. Kathmandu:

LAHURNIP, pp 29-52.

Rao, N. and A. Robinson-Pant (2006) Adult education and indigenous people:

Addressing gender in policy and practice, International Journal of Educational

Development, 26/2, pp 209-223

Robinson-Pant, A. (2016) Women, Literacy and Development: an overview, in Hornberger, N. (ed), The Encyclopaedia of Language and Education, Vol. 2 Literacy (3rd. Edition), New York: Springer

Rogers, A. (2013) The Classroom and the Everyday: The Importance of Informal Learning for Formal Learning, in Investigar Em Educacao Vol 1, no 1, 2014 pp 7-34, University of Minho, Braga, Portugal

SAARC (2015) New Delhi Agreement for enhancing SAARC collaboration for Education 2030: adopted by the participants of the Sub-Regional Conference on 'EFA Unfinished and Post 2015 Education Agendas in SAARC countries,'13 -14 October 2015, New Delhi, India

Street, B.V. (1984) Literacy in Theory and Practice, Cambridge: Cambridge University Press

Street, B.V. (2005) Literacy Across Educational Contexts, Philadelphia, USA: Caslon Publishing

The Asia Foundation (2011) Political economy analysis of local governance in Nepal with special reference to education and health sectors. Kathmandu: Author.

Thomas, D., S. Bell, K. Dahal, R. Grellier, C. Jha, S. Prasai, and H. N. Subedi (2012) Voices from the Community: Access to Health Services a Rapid Participatory Ethnographic Evaluation and Research (PEER). Kathmandu: Population Division, Ministry of Health and Population.

Tough, A. (1979) Adults' learning projects. Toronto: OISE.

UN (2015) Transforming our world: The 2030 Agenda for Sustainable Development, Draft resolution referred to the United Nations Summit for the adoption of the post2015 development agenda by the General Assembly, $18^{\text {th }}$ September 2015

UNESCO (2006) A 10-year literacy/NFE policy and programme framework. Kathmandu: UNESCO

UN (2008) United Nations Declaration on the Rights of Indigenous People, New York: United Nations

Vinding, D. and Kampbel, E. R. (2012). Indigenous women workers with case studies from Bangladesh, Nepal and the Americas. Geneva: ILO Bureau for Gender Equality 
World Conference of Indigenous Peoples on Territory, Environment and Development (1992), Kari-Oca Declaration and Indigenous Peoples' Earth Charter, Kari Oca 25-30 May 1992

WIPCE (1999) Coolongatta Statement on Indigenous People's Rights in Education at the World Indigenous Peoples' Conference on Education in Hilo, Hawai'I, 1999: accessed from http://ankn.uaf.edu/IKS/cool.html 
Table 1. Recognition of indigenous women in international treaties

\begin{tabular}{|c|c|c|c|c|c|}
\hline \multirow[t]{2}{*}{ Treaties } & \multicolumn{2}{|c|}{ Approaches to Adult Education } & \multicolumn{3}{|c|}{ Recognition of Indigenous peoples, knowledge and learning } \\
\hline & $\begin{array}{l}\text { Adult education, } \\
\text { learning and } \\
\text { literacy }\end{array}$ & $\begin{array}{l}\text { Knowledge, skills } \\
\text { and capacities } \\
\text { promoted }\end{array}$ & $\begin{array}{l}\text { Aims for indigenous } \\
\text { women and } \\
\text { education }\end{array}$ & $\begin{array}{l}\text { Representation of } \\
\text { indigenous women and } \\
\text { their knowledge }\end{array}$ & $\begin{array}{l}\text { Indigenous } \\
\text { language needs }\end{array}$ \\
\hline $\begin{array}{l}\text { International } \\
\text { Convention on } \\
\text { Economic, Social } \\
\text { and Cultural } \\
\text { Rights (1966) }\end{array}$ & $\begin{array}{l}\text { Human rights stance, } \\
\text { declaring the right of } \\
\text { everyone to } \\
\text { education (Art 13) } \\
\text { Fundamental (basic) } \\
\text { education for those } \\
\text { not completing } \\
\text { primary education } \\
\text { encouraged }\end{array}$ & $\begin{array}{l}\text { Concerned with "full } \\
\text { development of the } \\
\text { human personality" } \\
\text { reiterating the UN } \\
\text { Declaration of } \\
\text { Human Rights (Art } \\
\text { 26) } \\
\text { Life-long learning } \\
\text { introduced in GC } 13\end{array}$ & $\begin{array}{l}\text { No mention of } \\
\text { indigenous women in } \\
\text { Articles, but } \\
\text { referenced in General } \\
\text { Comments. }\end{array}$ & $\begin{array}{l}\text { No specific mention of } \\
\text { indigenous } \\
\text { peoples/women, or IK. } \\
\text { Notes education has } \\
\text { value in passing on } \\
\text { cultural values, religion, } \\
\text { customs, language and } \\
\text { other cultural } \\
\text { references... and respect } \\
\text { for cultural values }\end{array}$ & $\begin{array}{l}\text { Calls for non- } \\
\text { discrimination on } \\
\text { basis of language. } \\
\text { Reference to } \\
\text { language barriers, } \\
\text { needs of minorities } \\
\text { in GC } 20 .\end{array}$ \\
\hline $\begin{array}{l}\text { Convention on the } \\
\text { Eradication of } \\
\text { Discrimination } \\
\text { against Women } \\
\text { (1980) }\end{array}$ & $\begin{array}{l}\text { Focus on rights and } \\
\text { equal access to } \\
\text { education for } \\
\text { women/men, at all } \\
\text { levels of education } \\
\& \text { training, including } \\
\text { adult and functional } \\
\text { literacy }\end{array}$ & $\begin{array}{l}\text { Limited mention of } \\
\text { knowledge and } \\
\text { skills. Health and } \\
\text { family planning } \\
\text { information } \\
\text { prioritised. }\end{array}$ & $\begin{array}{l}\text { No mention of } \\
\text { indigenous women. }\end{array}$ & $\begin{array}{l}\text { No specific mention of } \\
\text { indigenous } \\
\text { peoples/women. } \\
\text { Recognition of the } \\
\text { influence of culture and } \\
\text { tradition, but only in } \\
\text { terms of restricting } \\
\text { women's rights }\end{array}$ & $\begin{array}{l}\text { Calls for non- } \\
\text { discrimination on } \\
\text { basis of language } \\
\text { (Art. 2.2) }\end{array}$ \\
\hline $\begin{array}{l}\text { Rio Declaration } \\
\text { on Environment } \\
\text { and Development } \\
\text { (1992) }\end{array}$ & $\begin{array}{l}\text { Instrumental role of } \\
\text { education - catalyst } \\
\text { for environmental } \\
\text { awareness and } \\
\text { sustainable }\end{array}$ & $\begin{array}{l}\text { Calls for } \\
\text { introduction of } \\
\text { environment and } \\
\text { development issues }\end{array}$ & $\begin{array}{l}\text { Incorporate } \\
\text { indigenous peoples' } \\
\text { experience and } \\
\text { understanding of } \\
\text { sustainable }\end{array}$ & $\begin{array}{l}\text { Calls for recognition \& } \\
\text { application of indigenous } \\
\text { values, traditional } \\
\text { knowledge and resource }\end{array}$ & $\begin{array}{l}\text { No mention of } \\
\text { language(s) }\end{array}$ \\
\hline
\end{tabular}




\begin{tabular}{|c|c|c|c|c|c|}
\hline & $\begin{array}{l}\text { development; Halve } \\
1990 \text { levels of } \\
\text { 'illiteracy' }\end{array}$ & $\begin{array}{l}\text { into all education } \\
\text { programmes }\end{array}$ & $\begin{array}{l}\text { development into } \\
\text { education, training }\end{array}$ & $\begin{array}{l}\text { management to support } \\
\text { sustainable development }\end{array}$ & \\
\hline $\begin{array}{l}\text { Beijing Platform } \\
\text { for Action (1995) }\end{array}$ & $\begin{array}{l}\text { Education as a } \\
\text { human right and } \\
\text { instrumental for } \\
\text { achieving equality. } \\
\text { Focus on gender } \\
\text { equitable access to - } \\
\text { and treatment in - } \\
\text { education, } \\
\text { eliminating gender } \\
\text { gap in literacy. } \\
\text { Literacy, life-long } \\
\text { education \& training } \\
\text { for women } \\
\text { recognised as means } \\
\text { to achieve economic } \\
\text { growth \& } \\
\text { sustainable } \\
\text { development. }\end{array}$ & $\begin{array}{l}\text { Promotes non-formal } \\
\text { education for adult } \\
\text { women, to acquire } \\
\text { skills in: health, } \\
\text { micro-enterprise, } \\
\text { agriculture and legal } \\
\text { rights; } \\
\text { Promotes vocational } \\
\text { training, leadership } \\
\text { \& management and } \\
\text { STEM; }\end{array}$ & $\begin{array}{l}\text { Recognizes the right } \\
\text { of indigenous } \\
\text { women and girls to } \\
\text { education; } \\
\text { Acknowledges } \\
\text { indigenous women as } \\
\text { underserved group. } \\
\text { Promotes a } \\
\text { multicultural } \\
\text { approach responsive } \\
\text { to the needs, } \\
\text { aspirations and } \\
\text { cultures of } \\
\text { indigenous women. }\end{array}$ & $\begin{array}{l}\text { Extensive reference to } \\
\text { indigenous women. } \\
\text { Acknowledges } \\
\text { traditional knowledge as } \\
\text { a form of lifelong } \\
\text { learning. } \\
\text { Calls for respect for } \\
\text { artistic, spiritual and } \\
\text { cultural activities of } \\
\text { indigenous women; } \\
\text { Calls for protection and } \\
\text { use of the knowledge, } \\
\text { innovations and practices } \\
\text { of indigenous women }\end{array}$ & $\begin{array}{l}\text { Promotes } \\
\text { development of } \\
\text { appropriate } \\
\text { education } \\
\text { programmes, } \\
\text { curricula \& teaching } \\
\text { aids in indigenous } \\
\text { languages }\end{array}$ \\
\hline $\begin{array}{l}\text { UN Declaration } \\
\text { on the Rights of } \\
\text { Indigenous } \\
\text { Peoples (2007) }\end{array}$ & $\begin{array}{l}\text { No specific mention } \\
\text { of adult education. } \\
\text { Education as a } \\
\text { reflection of the } \\
\text { dignity/diversity of } \\
\text { cultures, traditions, } \\
\text { histories and } \\
\text { aspirations }\end{array}$ & $\begin{array}{l}\text { Traditional } \\
\text { knowledge and } \\
\text { cultural expressions, } \\
\text { their sciences \& } \\
\text { technologies: inc. } \\
\text { human and genetic } \\
\text { resources, } \\
\text { medicines, } \\
\text { knowledge of }\end{array}$ & $\begin{array}{l}\text { Indigenous peoples } \\
\text { have the right to } \\
\text { establish and control } \\
\text { their } \\
\text { education } \\
\text { systems/institutions } \\
\text { providing education } \\
\text { in a manner }\end{array}$ & $\begin{array}{l}\text { Recognises indigenous } \\
\text { peoples' right to protect } \\
\text { and develop their } \\
\text { traditional knowledge, } \\
\text { cultural heritage and } \\
\text { intellectual property. } \\
\text { Respect for indigenous } \\
\text { knowledge, cultures and } \\
\text { practices contributes to }\end{array}$ & $\begin{array}{l}\text { Call for states, } \\
\text { alongside indigenous } \\
\text { peoples, to ensure } \\
\text { that indigenous } \\
\text { individuals - when } \\
\text { possible - have } \\
\text { access to education } \\
\text { in their own }\end{array}$ \\
\hline
\end{tabular}




\begin{tabular}{|l|l|l|l|l|l|}
\hline & $\begin{array}{l}\text { fauna/flora, oral } \\
\text { traditions, literatures, } \\
\text { sports, visual and } \\
\text { performing arts (Art } \\
31) .\end{array}$ & $\begin{array}{l}\text { appropriate to their } \\
\text { cultural methods of } \\
\text { teaching and learning } \\
\text { (Art 14) }\end{array}$ & $\begin{array}{l}\text { sound environmental } \\
\text { management \& } \\
\text { sustainable, equitable } \\
\text { development } \\
\text { Indigenous women as } \\
\text { disadvantaged group. }\end{array}$ & $\begin{array}{l}\text { language and culture } \\
\text { (Art 14). }\end{array}$ \\
\hline
\end{tabular}


Table 2: International Commitments to Education and role of Indigenous Women

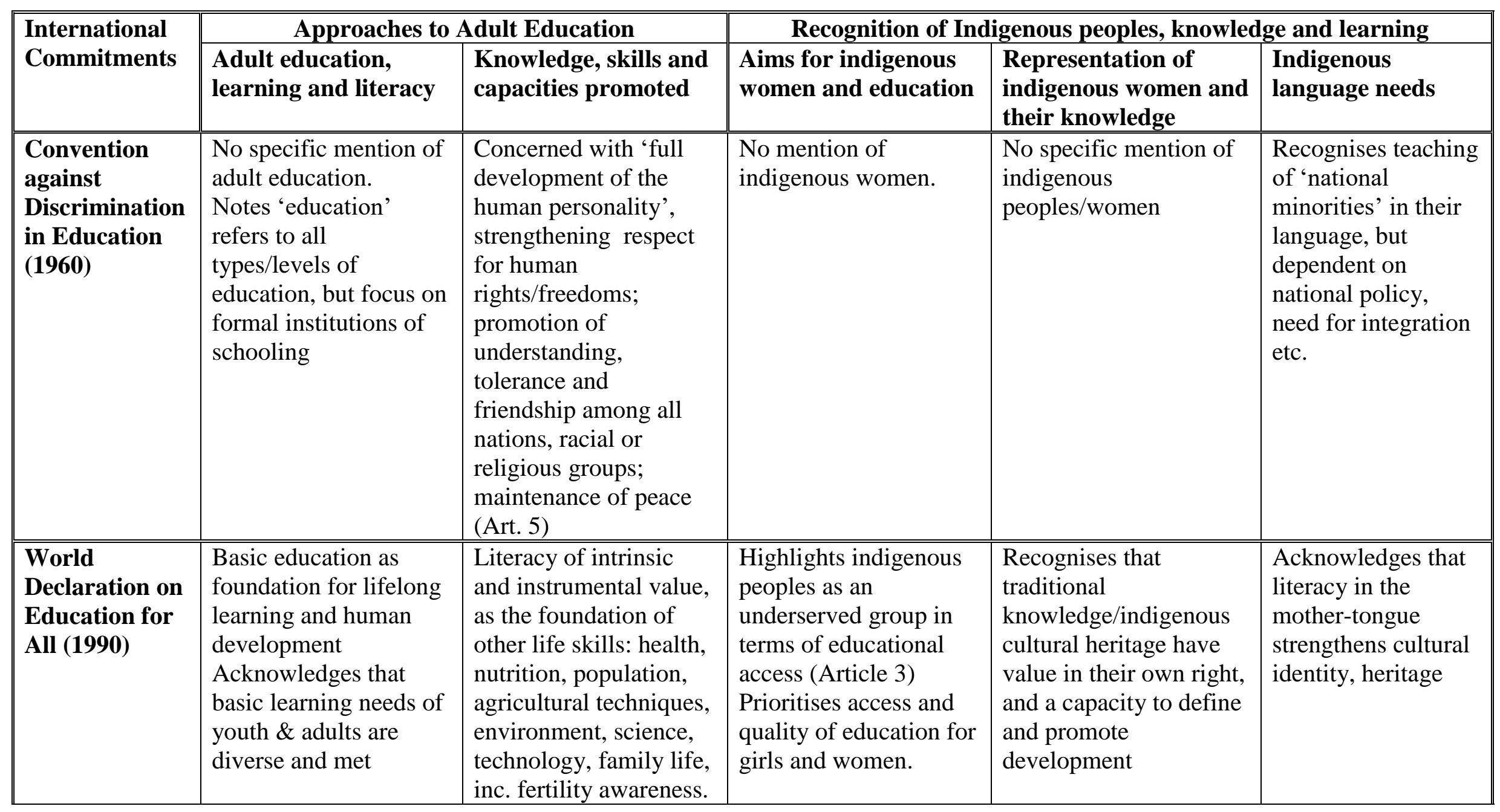




\begin{tabular}{|c|c|c|c|c|c|}
\hline & $\begin{array}{l}\text { through variety of } \\
\text { delivery systems }\end{array}$ & & & & \\
\hline $\begin{array}{l}\text { Dakar } \\
\text { Framework } \\
\text { for Action for } \\
\text { EFA }(\mathbf{2 0 0 0 )}\end{array}$ & $\begin{array}{l}\text { Education of intrinsic } \\
\text { and instrumental value. } \\
\text { Calls for expanded } \\
\text { adult/continuing } \\
\text { education, and } \\
\text { integrated into national } \\
\text { education and poverty } \\
\text { reduction strategies. } \\
\text { Closer linkages among } \\
\text { formal, non-formal, } \\
\text { informal adult learning. }\end{array}$ & $\begin{array}{l}\text { Literacy as } \\
\text { fundamental for } \\
\text { lifelong learning, } \\
\text { sustainable livelihoods, } \\
\text { health, citizenship. } \\
\text { Literacy and continuing } \\
\text { education for women's } \\
\text { empowerment and } \\
\text { equality. }\end{array}$ & $\begin{array}{l}\text { Reiterates stance of } \\
\text { EFA: indigenous } \\
\text { peoples are an } \\
\text { underserved group in } \\
\text { educational access. }\end{array}$ & $\begin{array}{l}\text { Reiterates EFA stance- } \\
\text { that traditional } \\
\text { knowledge/indigenous } \\
\text { cultural heritage have a } \\
\text { value and validity in } \\
\text { their own right, and } \\
\text { capacity to define and } \\
\text { promote development }\end{array}$ & $\begin{array}{l}\text { Acknowledges the } \\
\text { importance of local } \\
\text { languages for } \\
\text { literacy. }\end{array}$ \\
\hline $\begin{array}{l}\text { Belém } \\
\text { Framework } \\
\text { for Action: } \\
\text { Adult } \\
\text { Learning and } \\
\text { Education } \\
(2009)\end{array}$ & $\begin{array}{l}\text { Adult education } \\
\text { positioned within a } \\
\text { lifelong, life-wide } \\
\text { learning perspective, to } \\
\text { address all aspects of } \\
\text { human development } \\
\text { (economic, social, } \\
\text { personal) }\end{array}$ & $\begin{array}{l}\text { Knowledge, } \\
\text { capabilities, skills, } \\
\text { competences and } \\
\text { values to advance } \\
\text { individuals' rights and } \\
\text { destinies, achieve } \\
\text { equitable, inclusive and } \\
\text { sustainable societies; } \\
\text { skills/competences for } \\
\text { new work } \\
\text { environments, social } \\
\text { organisation and } \\
\text { communication }\end{array}$ & $\begin{array}{l}\text { No specific mention of } \\
\text { indigenous women. } \\
\text { Support for literacy in } \\
\text { indigenous languages } \\
\text { by developing } \\
\text { programmes, methods, } \\
\text { materials that value } \\
\text { indigenous cultures, } \\
\text { knowledge and } \\
\text { methodologies }\end{array}$ & $\begin{array}{l}\text { No specific mention of } \\
\text { indigenous women. } \\
\text { Indigenous peoples } \\
\text { represented as highly } \\
\text { disadvantaged } \\
\text { populations }\end{array}$ & $\begin{array}{l}\text { Multilingual/mother } \\
\text { tongue policies } \\
\text { necessary for } \\
\text { creating a literate } \\
\text { environment, } \\
\text { especially for } \\
\text { indigenous/minority } \\
\text { groups }\end{array}$ \\
\hline
\end{tabular}

${ }^{5}$ Examples provided include: skills training, apprenticeships, and formal and non-formal education programmes and media (article 3) 
Figure 1. International Treaties and Declarations with a focus on Education

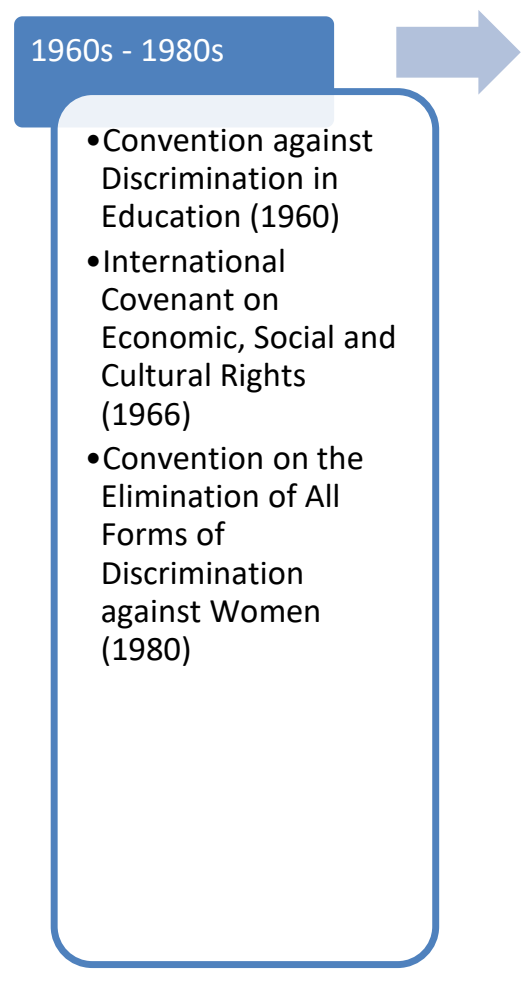

1990s-2000s
- World Declaration
on Education For All
(1990)
- Rio Declaration on
Environment and
Development (1992)
- Beijing Platform for
Action (1995)
- MDGs (2000)
- Dakar Framework
for Action for EFA
(2000)
-Rio +10 (2002)
- UN Declaration on
the Rights of
Indigenous Peoples
(2007)
-Belém Framework
for Action (2009)

-UN post-2015 Task
Team
- Rio +20 OWG (2012)
-SAARC New Dehli
Declaration on
Education (2014)
-SDGs (2015)
-Beijing + 20 Global
Leaders' Meeting on
Gender Equality and
Women's
Empowerment (2015)
-Inter-Agency and
Expert Group on SDG
Indicators (IAEG-SDGs)
(2016)

